\title{
Postkolonialismus a dekolonizace: základní vymezení a inspirace pro sociální vědy'
}

\author{
Post-colonialism and Decolonization: Basic Specification \\ and Inspiration for the Social Sciences
}

Ondřej Lánský

\begin{abstract}
This theoretical study engages with the methodological and theoretical contributions of post-colonial thought to the contemporary social sciences and the understanding of modern society and the trends in its development. The article first introduces selected fundamental themes of post-colonial thought and, second, it seeks to contextualize the general framework of post-colonialism in the Czech scientific environment in order to adequately use it in social analysis. This article gradually introduces some of the important post-colonial themes: the critique of violence connected with European rationality (reason), the critique of generalized racism, and, finally, the consideration of identity and subjectivity. The very goal of this article is to grasp depicted elements and to provide, through this, post-colonially informed instruments of social science for the investigation of poverty, racism and social exclusion in the Czech Republic.
\end{abstract}

KEY WORDS Decolonial turn, labour, postcolonial theory, racism, Roma, social exclusion

$\mathrm{Na}$ konci 50. let napsal Aimé Césaire svůj slavný text Rozprava o kolonialismu (Césaire 2011), ve kterém tematizuje některé ze zásadních otázek (post)koloniální situace. Od té doby se postupně otevírá prostor pro zkoumání sociální, ekonomické i politické situace v čerstvě dekolonizovaných či právě osvobozovaných společnostech tzv. třetího světa ${ }^{2}$, tedy situace ve společnostech bývalých evropských kolonií. Vlna poválečných politických dekolonizací však byla teprve začátkem ,léčby“, kterou měly tyto společnosti projít. Postupně se ukázalo, že šrámy, které zanechal na strukturách těchto společností i na duších jedinců politicko-ekonomický řád kolonialismu, jsou mnohem hlubší, než se mohlo zdát. Autoři jako Frantz

Sociální studia. Katedra sociologie FSS MU, 1/2014. S. 41-60. ISSN 1214-813X.

1 Tento text vznikl jako výsledek autorovy vědecké a výzkumné činnosti v rámci Centra globálních studií Akademie věd České republiky a Univerzity Karlovy.

2 Autorem tohoto termínu je francouzský antropolog a historik Alfred Sauvy, který jej poprvé použil $\mathrm{v}$ roce 1952. Tímto označením popsal skupinu států, které vznikaly v rámci vlny dekolonizace po druhé světové válce. Metaforou mu bylo označení třetí stav z francouzské revoluce, a to nejen metaforou deskriptivní, ale také preskriptivní: domníval se, že stejně jako francouzská revoluce byla do značné míry emancipací třetího stavu, tak nastávající éra mezinárodní politiky musí být věnována emancipaci dekolonizovaných států a společností (srov. Giddens 1999: 78). 
Fanon (2011) či Albert Memmi (1991) postupně odhalovali tuto bolestnou zkušenost a každé z jejich děl otevíralo další prostor pro kritické zkoumání. V 70. letech potom přichází emblematická publikace Edwarda W. Saida Orientalismus (Said 2008), která již předznamenává nástup nového pole či prostoru teoretických i praktických vědeckých př́stupů tím, že otevřeně kritizuje způsob evropského uchopování reality. Ukazuje mj., jak epistemologie evropských věd zvěcňuje druhého a připravuje jej tak skrze psychické a sociální struktury, které logicky zasahují ovládající i ovládané, na zvěcnění. Orientalismus tak poprvé naznačuje jasnou vazbu mezi poznáním a mocí na konkrétním př́íkladu určité postkoloniální situace; totiž na vztahu Západu/Evropy a orientalizovaného Orientu. Do značné míry tak také vymezuje program postkoloniálního myšlení až do dnešních dnů: jde mu o převrácení náhledu na vztah mezi ekonomikou či politikou a v obecném významu kulturou. Zatímco např. marxismus klasicky identifikuje formy sociálně podmíněných nespravedlností z hlediska práce (tedy sociálních vztahů týkajících se práce) a např. kulturu vnímá jako v lepším př́ípadě zprostředkující médium, tak postkolonialismus ukazuje - a v tom je jeho nejvýraznější rozdíl oproti marxismu - to, že kultura (a konkrétně struktury myšlení) je ve skutečnosti původním prostorem, kde se odehrává sociálně-psychologická „příprava“ subjektů k ovládání či vykořist'ování. $Z$ tohoto důvodu se mnohé pojmy a argumenty postkolonialismu jeví jako marxistické, avšak nejsou, jelikož klasický marxismus neidentifikoval problémy na této rovině analýzy. ${ }^{4}$ Marxismus systematicky nevnímá jako problém západní či dříve evropské systémy vědění, které svou výstavbou (viz níže) podporují a v tomto smyslu také vlastně předcházejí západní kolonialismus, a tudíž i modernitu a kapitalismus.

Od 90. let 20. století jsme potom svědky epistemického dekoloniálního obratu (např. Maldonado-Torres 2011), který je významným a hlubokým interdiciplinárním či transdisciplinárním metodologickým procesem proměňujícím eurocentrický charakter sociálních věd a věd o člověku. Svůj ontologický původ má v souboru nejrůznějších tzv. postkoloniálních teorií či v tzv. postkolonialismus. Postkoloniální myšlení přibližně od 50. či 60. let 20. století představuje jeden z nejvýznamnějších kritických diskursů zkoumání společnosti. Vedle něj je možné k těmto kritickým diskursưm řadit i feminismus, poststrukturalismus, post/neo/marxismus či psychoanalýzu. Postkolonialismus spolu se zmíněným obecnějším procesem ve vědě a filosofii - dekoloniálním obratem - může ztělesňovat výzvu nejen pro teorie, které mapují a analyzují sociální procesy a jednotlivé fenomény v souvislosti s koloniálními vztahy a postkoloniální situací, ale také pro další vědecké disciplíny a subdisciplíny tím, že se pokouší odhalovat problematické základy klasických věd o společnosti, a také tím, že odhaluje určitá zjištění ohledně obecného charakteru moci tak, jak se rozvinula v souvislosti s dějinami západní modernity (a tudíž i kolonialismu). Domnívám se, že pro areál sociálních věd (sociologii, sociální filosofii, antropologii či sociální psychologii) představuje dekoloniální obrat a celý heterogenní soubor tzv. postkolonialismu výzvu a příslib nového přístupu ke zkoumání sociální skutečnosti.

Část této knihy vyšla také v českém překladu - viz Memmi (1997).

Obdobně vidí vztah postkolonialismu a marxismu např. Gandhi (1998: 25-26).

Tyto dva pojmy budu $\mathrm{v}$ této studii používat do značné míry jako synonyma. 
V tomto článku se pokusím naznačit některé z možných směrů využití postkoloniálních metodologických postupů a od postkolonialismu odvozených inspirací pro sociální vědy v českém kontextu. Centrální téma postkolonialismu, které se v různých podobách (někdy dokonce zcela implicitně) prolíná textem a také vůbec postkoloniálním myšlením, je potom (postkoloniální) otázka moci. Postkolonialismus má tu schopnost, že může tuto kategorii nasvítit v poněkud novém světle, které není klasickým evropským formulacím sociálních věd snadno přístupné. Pokud připustíme, že naše společnost je společností, která je ontologicky nerozlučně spojena s kolonialismem, je studium nejrůznějších aspektů postkoloniální situace téměř povinností. Tedy je-li naším cílem společnosti porozumět.

Nejprve je tedy potřeba se stručně seznámit s obecným rámcem postkoloniálního myšlení. V první části článku se tedy zaměřím na základní kontury postkolonialismu. Ve druhé části se podrobněji soustředím na několik konkrétních vybraných témat postkolonialismu: na kritiku násilí vázaného na evropskou racionalitu (kritika epistemologie), na kritiku v koloniálním řádu zobecněného rasismu (kritika rasisticky orientovaného násili) a konečně na některé postkolonizované aspekty zkoumání identity a subjektivity (kritika stereotypu). $\mathrm{V}$ poslední části článku se budu věnovat usouvztažnění popsaných problémových okruhů postkolonialismu a zaměřím se na potenciál využitelnosti postkolonialismu pro analýzu chudoby, rasismu a sociálního vyloučení v České republice. Dotknu se tak možných konkrétních inspirací pro společenské vědy. Text předkládané studie tak může být chápán jako pokus o základní vymezení programu dekolonizace české sociální vědy ${ }^{6} \mathrm{v}$ tom smyslu, že seznamuje s postkoloniální kritikou gnozeologických východisek euroatlantické epistemologie a vědy o společnosti a člověku a zároveň přibližuje program dekolonizace sociálněvědního diskursu z hlediska obsahu, přičemž tato dekolonizace by měla probíhat zevnitř sebe sama v produktivní komunikaci s autentickým myšlením třetího světa.

\section{Základní kontury postkolonialismu}

Postkoloniální myšlení je druhem angažované sociální vědy. To znamená, že s sebou nenese pouze schopnost vědce kriticky reflektovat společnost či její fenomény, ale také předpokládá osobní nasazení a odvahu samotných vědců a vědkyň (Dussel 1977: 188-191). Téměř přirozenou součástí postkoloniálního diskursu je tak určitý osobní rozměr; většina autorů a autorek se vyrovnává bud' s důsledky postkoloniální situace ve svém životě, anebo s kulturně sdílenou vinou za kolonizaci. V obou př́padech ústí tento osobní rozměr do určité angažovanosti, která mnohdy nabývá podoby zcela otevřeného politického zapojení se do pro autora či autorku současných sociálních bojů. Tento moment je pro klasickou sociologii určitou překážkou, nebot' vzhledem k jejímu důrazu na odmítání hodnocení ve vědě je náročné přijmout politickou angažovanost jako moment, který neochuzuje toto myšlení/zkoumání o vědeckost. Angažovanost v tomto smyslu znamená také zakotvenost a vztah východisek, argumentace i závěrů výzkumů ke konkrétní sociální pozici, zkrátka lokalizaci poznání. Postkoloniální

6 Obdobně postupuje ve své práci i Pavel Barša, který se ale soustředí na širší kontext současného sociálního a politického myšlení zaměřený na vztah většin k menšinám (srov. např. Barša 2011). 
teorie tedy navazují minimálně v tomto bodě na kritickou teorii frankfurtské školy a zároveň v postoji k angažovanosti badatelů a badatelek sdílí stanoviska feministické sociologie.

Základem pro pochopení toho, o co postkolonialismu jde, je správně porozumět, k čemu v kolonizovaných společnostech vlastně došlo a jaké důsledky kolonizace v zasažených společnostech přináší - na rovině sociální, psychologické, kulturní i ekonomické - dodnes. Proto je důležitým prvkem angažované kritiky důsledná analýza zkoumaného fenoménu. Jak jsem již uvedl výše, patří postkoloniální myšlení/postkolonialismus mezi několik klíčových sociálně kritických paradigmat současnosti, nebot’ tematizuje patologické projevy západní modernity z pohledu až do přibližně 50. a 60. let 20. století mlčící, resp. umlčované části světa. Východiskem i cílem je pro postkolonialismus perspektiva utlačovaných v rámci kolonizace. Přestože v mnohém postkolonialismus čerpá z marxistické kritiky modernity či ze (západního) poststrukturalistického zpochybnění nároků západní epistemologie, to, co jej jasně vymezuje, je právě historická perspektiva koloniálních (makro i mikrosociálních) vztahů a různých aspektů, ze kterých modernita teprve povstala. Zásadní a nejobecnější vklad postkolonialismu spočívá ve dvou bodech: v kritice západního způsobu poznávání světa (západní epistemologii) a v odhalování rasistických pilírů západních sociálně sdílených kulturních vzorců, které se nejvíce projevovaly prostřednictvím různých forem hegemonie, a to právě během evropské kolonizace. Pojem kulturního vzorce zde odkazuje k širšímu významu pojmu kultura, kdy označuje obsah a působnost určitých sociálních vzorců jednání, které formují nejen sociální jednání aktérů, ale také určují klíčové charakteristiky dané společnosti jako takové. Jako jedny z výrazných zdrojů těchto vzorců je možné v určité návaznosti na Charlese Taylora vnímat sdillené sociálně-normativní predstavy (neboli představy společnosti), které označují pojmové a argumentační soustavy nebo filosofické tradice za natolik přesvědčivá sebereflexivní vyjádření své doby a geografického místa vzniku, že - bez ohledu na autory zamýšlenou interní metodologickou charakteristiku (deskripci, kritiku nebo normativitu) - mohou sloužit jako analyticky využitelný materiál pro kritickou analýzu forem a projevů morálního pozadí sociálních vzorců (Taylor 2013: 9-102). A právě z tohoto důvodu je důležité se ptát obecně i konkrétně po sociální roli epistemologie a filosofie vůbec v evropské kolonizaci? ${ }^{7}$.

Postkoloniální situace, která stojí v centru pozornosti postkolonialismu, spočívá v binárním rozdělení světa: Já versus Druhý ${ }^{8}$. Toto základní binární rozdělení působí prostřednictvím epistemologie a jazyka v rámci ekonomické, sociální, kulturní i psychologické oblasti života tak, že vytváří jakousi mřŕžku, skrze niž je svět nejen vnímán a interpretován, ale také

7 Např. Nelson Maldonado-Torres či Ramón Grosfoguel z tohoto důvodu věnují nemalou část své pozornosti právě dekoloniální kritice karteziánského obratu či dalších velkých filosofických teorií společnosti, poznání či identity (např. Hegel, Marx ad.). Srov. Grosfoguel (2013); MaldonadoTorres $(2008,2013)$.

8 Tento obraz je v rámci postkoloniálního myšlení natolik všeobecný, že nelze odkázat na jednoho autora. V českém jazykovém prostředí spíše poukážu na velmi zajímavý text Veroniky SušovéSalminen, který se zabývá latinskoamerickou variantou postkoloniálně orientované kritiky modernity, přičemž zároveň Sušová-Salminen v tomto textu nabízí přehlednou analýzu pojmu druhého a jeho funkci v rámci koloniálního diskursu (Sušová-Salminen 2012: 85-87). 
v rovině sociálních důsledků jednání vlastně teprve vytvářen. Mexicko-argentinský filosof Enrique Dussel (1995) či bulharsko-francouzský filosof a literární kritik Tzvetan Todorov (1996) v této souvislosti říkají, že evropský člověk byl sám dotvořen skrze druhého, kterého stvořil v kolonizaci tím, že ovládl společenské rády dobytých území. Oba tito autoři své závěry formulují na př́kladu Latinské Ameriky, ale domnívám se, že je lze v této souvislosti zobecnit. Na jedné straně tak stojí běloch (který je kódovaný jako dobro, civilizace, dospělost) a na straně druhé černoch/indián/barevný (který je zase kódovaný jako zlo, barbarství či infantilita). Kromě této mikrosociální či intersubjektivní roviny má tento moment také svůj makrosociální rozměr $\mathrm{v}$ tom, že právě prostřednictvím kolonizace byl postupně rozšířen kapitalistický výrobní způsob po bezmála celé planetě. Na kolonizaci a odpovídající historicky podmíněný vznik post/koloniálních sociálních vzorců (tedy na tento makrosociální moment) reaguje mimo jiné Dusselova filosofie osvobození (Dussel 2007, 2009a, 2009b), která je jednou z komplexních artikulací myšlení z okraje kapitalistického řádu (srov. s Lánský 2012) a která zároveň rozvíjí metodologický, teoretický a praktický program osvobození a odpoutání se od post/koloniální moci.

Popsaná binární opozice - tedy zmíněná mřižka - vlastně všem zúčastněným napovídá jejich arbitrární pozici v rámci společenského řádu kolonizace. $\mathrm{K}$ její internalizaci dochází prostřednictvím systému vzdělávání a pomocí celého systému sociálně sdílených kulturních vzorců. Tato binární struktura západního/evropského způsobu vztahování se k druhému má pravděpodobné jádro $\mathrm{v}$ unikátní pozici, která je poskytnuta jedinci - egu, jež se rozvinula v rámci evropské epistemologie nejpozději v kontextu karteziánského filosoficko-vědeckého obratu9. Ten totiž do centra poznávání jako procesu postavil právě ego/individuum a založil tak moc poznat, pochopit, komunikovat a $\mathrm{v}$ neposlední řadě také uchopit na jedinci uvolněném od všech forem ujařmujícího zakotvení. Progresivní moment, který se zde skrývá, je nabíledni: Descartes vlastně završuje renesanční obrat ve fillosofii a formuluje konečné odebrání autority poznávání církvi či jiným tradičním institucím. Budoucí člověk bude za poznávání, ale také za moc a její projevy, zodpovědný sám a bude muset vytvářet ad hoc zdůvodnění svého jednání. Samožrejmě, že i tyto formy legitimizace násilí nabývají kolektivních podob, avšak moderní člověk je vržen do určité svobody, nebot' jeho jednání je mnohem více založeno na vlastním poznání než jednání člověka tradičního. Ambivalentní náboj tohoto (částečného) osvobození se nejvíce projevil v evropské kolonizaci a zároveň kolonizaci na bazální rovině vlastně popisuje. Poznání je např́šstě odvozeno od primátu rozumu, který zcela patř́ jedinci. Toto pojetí rozumu je potom považováno za univerzální a jakékoliv jiné pojetí je bráno za méněcenné a nedostatečné.

9 Kritikou okcidentálního pojetí rozumu, které je přirozeně etnocentrické, ale zároveň má v sobě požadavek po své univerzální platnosti, se zabývá množství autorů a autorek. Koneckonců právě Saidova kritika orientalismu, se kterou čtenáře seznamuji níže, patří mezi ně. Obecně se tato kritika drží teze, že evropská epistemologie představuje orientaci poznání, která poskytuje Evropanům možnost postavit se vnějším silám (přírodě, cizímu) s pocitem nadřazenosti a patřičným sebevědomím. Takto orientované kritiky se vlastně snaží ukázat na spojení mezi koloniální politickou mocí a evropskou filosofií (srov. např. Dussel 1977: 13-27). 
Největším problémem je zde to, že držitelem poznání ve skutečnosti samozřejmě není kdokoliv, ale naopak ten, který je v daném řádu moci ve výhodné sociálně-ekonomické pozici. Do nitra epistemologie se tak vkrádá určující mocenský mechanismus: ten, kdo napříště nebude mluvit jako my, nemůže být oním subjektem, který myslí. Jediné myšlení, které je v tomto modelu legitimní, je to, které ve své činnosti postupuje v hranicích a intencích vyznačených právě evropskou epistemologií. Bílý muž všude hledá projevy stejného, které signalizují, že nové je na stejné úrovni jako on, a tudíž je oním subjektem, který myslet vůbec může. Právě z tohoto důvodu může Kolumbus psát ve svých dopisech či denících o tom, že místní obyvatelé nehovoří a že bude třeba je naučit mluvit ${ }^{10}$.

Začleňování světa do interpretačního obrazu, který evropské Já vytváří pro svou orientaci, je podřízeno moci pramenící ze zcela konkrétního individualismu: západní/evropské Já je uschopněno k výrazným výpadům vůči všemu, co je možné označit jako ne-Já (vztah k jinakosti). V koloniální situaci je pak jako ne-Já konstruováno vše, co je jiné. Ruku v ruce s tímto aplikovaným konkrétním epistemologickým individualismem jde také konkrétní nejprve epistemologický -, posléze sociální a kulturní rasismus. Psýché a kultura se zde stávají nástroji koloniální moci. Zároveň však vzniká kruh: moc západního individua je graduálně posilována materialitou a faktickou mocenskou převahou získávanou právě prostřednictvím této moci.

Toto právě popsané základní vymezení koloniální zkušenosti se v určitých variantách a s určitými odlišnostmi objevuje u několika různých autorů. Jedním z nejvýznamnějších vymezení je pak pojem koloniality (coloniality) Aníbala Quijana (2007). Jeho cílem je jednak zachytit určující aspekty mocenské sociální asymetrie vtělené v koloniální situaci a jednak poukázat na působení těchto asymetrií v současnosti v globálním režimu kapitalistického uspořádání. Quijano současné světové uspořádání vidí jako historický důsledek evropského kolonialismu. V tomto bodě obdobně jako Enrique Dussel navazují analýzy Aníbala Quijana na světosystémovou teorii amerického sociologa Immanuela Wallersteina (1974, 1980, 1989, 2011), která kriticky zkoumá vznik evropského kapitalismu na základě hospodářských a sociálních dějin. Pro aktuální uspořádání světové společnosti je charakteristické, že především přetrvává nerovné rozdělení zdrojů ve prospěch evropské menšiny, přičemž tzv. modernita je od počátku spjata právě s kolonialitou. Moderní společnosti jsou genericky spojeny s kolonizací a s násilím kolonizace, které se projevuje nejen v politickém a ekonomickém útlaku, ale také v násilí kulturního a intersubjektivního typu. Kolonialita je tak pro Quijana souvztažným a vysvětlujícím pojmem vůči pojmu modernity/modernizace. Lakonicky by bylo možné říci, že není žádné modernity bez koloniality. V rámci dekolonizovaných společností je stále reprodukována specifická koloniální struktura moci založená na rasově, etnicky a antropologicky založené sociální diskriminaci. Klíčový je pro Quijana pojem rasy, jelikož kolonialita (kolonialita/modernita) se stává globálním hegemoniálním modelem moci určujícím vztahy práce tak, aby byl tento model schopen zajistit regulaci sociálních vztahů v kontextu koloniální dominance - rasa se stala pořádajícím principem dělby práce v globalizované kapitalistické společnosti.

10 Např. citace Kolumba z 12. října 1492: „Zlíbí-li se Našemu Pánu, na zpáteční cestě jich vezmu šest pro Vaše Výsosti, aby se naučili mluvit.“ Cit. podle Todorov (1996: 40). 
V současnosti - a pro dekolonizaci jako program sociálních věd právě tento moment představuje výzvu - je potom důležitým projevem koloniality tzv. kolonizace obrazotvornosti (imaginace) a schopnosti narativního zprostředkování zkušenosti, a to především u ovládaných, utlačovaných a opomíjených. Tato kulturní kolonizace se projevuje tím způsobem, že evropská kultura se v globálním kontextu stala univerzálně prosazovaným kulturním modelem. Vzájemně se kombinující a doplňující procesy omezení původních forem vědění, symbolů a systémů a dosazení svádějících vzorců evropských, které jsou přitažlivější (protože jsou spojeny s těmi, kdo mají mocenskou převahu), vedly k celoplanetárnímu prosazení teze o stejném a univerzálním rozvoji, který je předurčen a vyznačen právě evropskou imaginací a věděním. V rámci Latinské Ameriky prostřednictvím těchto procesů dochází $\mathrm{k}$ likvidaci celých společností ,[...] připravených o své vlastní vzorce formalizovaného, objektivizovaného, intelektuálního a hmotného či vizuálního vyjádření“ (Quijano 2007: 170). Situace koloniality je tak nejobecnější podobou moci a dominance, a to dokonce zprostředkovaně v postkoloniální situaci či obecně v situaci ne-koloniální, ale moderní1 ${ }^{11}$. Právě na tuto situaci reaguje pojem geopolitiky vědění (vytvořený Enrique Dusselem, avšak hojně rozpracovaný Walterem Mignolem - srov. nap̌r. s Mignolo 2000), který se snaží kriticky upozornit právě na etnocentrický charakter globálního pojetí univerzity, poznání a myšlení vůbec.

Západní/evropská kolonizace určitých částí Asie, Afriky a Latinské Ameriky sice započala vojenským bojem, jehož cílem bylo usurpování zdrojů a práce těchto druhých, avšak tato exploatace měla ještě další rozměr. Vzhledem k historické sociální dynamice evropských společností došlo k vytvoření systému sociálních praktik, které pomocí rasismu a individualismu formují specifickou podobu kulturního zázemí kolonizace do značné míry i v (post) koloniální situaci. Kolonizace jako zvěcňování, jak o tom píše Aimé Césaire v Rozpravě o kolonialismu (Césaire 2011: 93), respektive jako snaha o ovládnutí lidských statků, jak ř́ká Ngũgĩ Wa Thiong’o v Jazyce africké literatury (Thiong’o 2011: 239), byla umožněna neohraničeným západním individualismem, který na jedné straně uschopnil bílého Evropana $\mathrm{k}$ ovládnutí tzv. ne-civilizovaného a barbarského negra a na straně druhé stvořil podřízené já utlačovaných.

Zde popsané pojetí postkolonialismu také naznačuje, že evropské myšlení není dostatečné pro úplné porozumění skutečnosti, jelikož zmíněné momenty nevnímá a nereflektuje. Vlastně je možné říci, že samotná evropská věda je součástí koloniálního řádu moci, nebot' poskytuje alibi tomuto systému prostřednictvím této nereflektovanosti. Základem je vztahování se ke světu jako k objektu, který je dán k dispozici evropskému člověku (bílému muži). V tomto kontextu je adekvátní hovořit o tom, že myšlení přicházející z okraje koloniálního uspořádání - ze zemí třetího světa, z alterity - může kromě samotných výsledků své činnosti nabídnout také strukturu proměny metodologie sociálních věd, která se tak stává dekolonizovanou.

11 Tento moment bude později využit pro popis př́slibů postkolonialismu pro současné sociální vědy v České republice. 


\section{Vybraná témata posłkolonialismu: epistemologie, rasismus a stereotyp}

Mezi tři klíčová témata postkolonialismu, kterými se zde chci zabývat, patří kritika evropské epistemologie, rasistického rozdělení světa a obecný problém identity. V této souvislosti se zaměřím na Saidovu kritiku evropského orientalismu, která se stává ve svém zobecnění kritikou epistemologického násilí a moci; na Fanonovy analýzy psychopatologií kolonizace, které vyúst'ují v kritiku rasismu jako pořádajícího rámce evropské modernity; a konečně na Bhabhovo zkoumání stereotypu jako zpo̊sobu vytváření vlastní identity v rámci procesů kolonizace. Ve všech těchto př́padech se jedná o určité rozpracování problematiky moci, která se zdá být nakonec ústředním tématem postkoloniálního myšlení (viz výše). Ve všech třech př́padech je navíc možné nalézt jednotící prvek, který stojí v pozadí těchto analýz, a tím je poststrukturalistický př́stup k analýzám moci, jak jej naznačil Michel Foucault. Nejde v žádném prrípadě o př́sné následování Foucaultových postupů (koneckonců některé texty vznikaly v době, kdy Foucault tvořil, či dokonce dříve ${ }^{12}$ ); spíše je to tak, že Michelu Foucaultovi se podařilo velmi dobře vyjádřit základní metodologický rámec, který postkolonialismus využíval a dodnes hojně využívá. Nicméně v tomto textu není cílem se zabývat Foucaultem ani jeho pojetím moci, ale zaměřit se na vybrané problémy postkoloniálního myšlení, a proto se mu zde nebudu věnovat ${ }^{13}$. V této souvislosti se budu věnovat zejména třem výše zmíněným tématům, jež jsou uchopena ve třech klíčových textech.

Jak jsem již uvedl výše, Saidova kniha Orientalismus je pro postkoloniální myšlení přelomová, jelikož se v ní autor věnuje vazbě mezi mocí a poznáním. Na konkrétním př́ikladu na evropském uchopení Orientu - analyzuje obecné tendence evropského vědeckého prrístupu k druhému či k jinakosti vůbec. Především je třeba upozornit na to, že se jedná o epistemologickou kritickou studii, která analyzuje způsob poznávání. Snaží se analyzovat hlavní zdroje síly hegemonie evropského myšlení, jelikož ,[...] hlavním rysem evropské kultury je právě to, co z ní učinilo kulturu vládnoucí v rámci Evropy i mimo ni, totiž myšlenka nadřazeného postavení Evropy nad všemi neevropskými národy i kulturami“ (Said 2008: 17). Přestože je tedy tématem orientalismus, ve skutečnosti se jedná o studii týkající se kultury, dějin a moci. Základním cílem Saida je totiž ukázat a reflektovat určitou nevyhnutelnost spjatosti myšlení se sociální pozicí a geopolitickým kontextem. Velice názorně to ukazuje Said na př́íkladu kritiky orientalismu v momentu, kdy představuje jednu z definic orientalismu, jež odpovídá

[...] rozšiřrení jistého geopolitického povědomí do estetických, vědeckých, ekonomických, sociologických, historických a filologických textů; je to rozpracováni nejen základního geografického rozlišení (svět se skládá ze dvou nerovnoměrných částí, Orientu a Západu), nýbrž i celé řady ,zájmů‘, které - např́klad prostř̌ednictvím vědeckého výzkumu, filologické rekonstrukce, psychologické analýzy nebo geografického či sociologického popisu - nejen vytváríí, ale rovněž dále udržuje; je to jistá vůle či záměr (spíše než jejich pouhé vyjádření) porozumět tomu, co je očividně jiným (či alternativním a novým) světem a v některých případech tento svět ovládnout, manipulovat jím nebo si jej dokonce přivlastnit; a především je to diskurs, který však není v přímé

Frantz Fanon v mnohém teprve anticipuje pozdější analytické nástroje, které Foucault používá. A to samožrejmě v podobě spíše volné.

13 K pojetí moci dle Foucaulta, které oslovilo postkoloniální autorky a autory, viz např. Foucault (2003 či 2007). 
závislosti na politické moci jako takové, nýbrž je vytvářen a udržován prostřednictvím svého nerovného vztahu k různým druhům moci: politické (reprezentované nap̌r. koloniálními či imperiálními institucemi), intelektuální (např. u dominantních vědních oborů, jako jsou srovnávací lingvistika či anatomie, nebo některých současných politologických disciplín), kulturní (např. v oblasti tradičních názorů a kánonu v oblasti vkusu, literatury či hodnot), morální (např. v případě představ o tom, co ,oni‘ nejsou schopni pochopit nebo dělat stejně jako,my“). (Said 2008: 22-23)

Postupně Said analyzuje základní vymezení orientalismu, nejrůznější struktury a restrukturace orientalismu, kde se soustředí zejména na práce Silvestre de Sacyho či Ernesta Renana. Zabývá se v neposlední řadě orientalismem, jehož byl současníkem, tzn. orientalismem nejen britským a francouzským, ale také jeho americkou mutací. Hlavním prrínosem je to, že na rozsáhlém materiálu - který sahá od 13. století po současnost - ukazuje, že Východ či Západ nejsou ontologicky stabilní pojmy, ale naopak kulturně-politické konstrukce. Tyto řečové konstrukce - které se ve své radikální podobě projevují v řádu binárních hodnotících opozic - je navíc možné zneužít pro uchopení druhého: tedy pro manipulaci a ovládnutí. I u něj se projevuje osobní charakter postkoloniálního myšlení např. tím, že tvrdí:

Jsem přesvědčen, že jedním z našich úkolů je čelit zjednodušujícím formulím a abstraktním, avšak vlivným myšlenkám, jež odvádějí pozornost od konkrétní dějinné zkušenosti k ideologickým fikcím, metafyzickým konfrontacím a kolektivním emocím, a usilovat o jejich překonání. (Said 2008: 404)

Podstatou humanismu, který navrhuje ke splnění tohoto úkolu, je potom schopnost člověka otevřít se druhému spočívající v subjektivní schopnosti proniknout do života druhého v respektu vůči němu. Přesně o naplnění tohoto vymezení úkolu filosofie a sociálního myšlení se potom pokouší právě postkoloniální myšlení ve své šířce.

V roce 1952 vychází kniha Frantze Fanona Černá kůže, bílé masky (Fanon 2011), kterou je možné vnímat jako důležitou z několika hledisek. Jako jeden z prvních myslitelů přesunul pozornost z „objektivních“ procesů kolonizace a boje proti ní na její subjektivní a afektivní rovinu. Velkou část jeho díla představuje pokus o pochopení psychopatologie kolonizace. Poskytuje tak ovšem zároveň nástroj pro porozumění psychopatologii modernity. Tuto subjektivní rovinu však obohacuje také o kulturní moment, nebot' v jádru reprodukce koloniálních patologií nachází kulturní vzorce, a tedy sociálně sdílené vzorce kolektivního jednání. Jeho analýza je tak ve skutečnosti orientována intersubjektivně. Individualizovaná zkušenost je mu prostředkem pro otevření kolektivně sdílených a implementovaných struktur násilí a utlačování sociální kritice.

Obdobně jako pro Quijana je i pro Fanona jádrem problému, resp. klíčem k jeho kritice, pojem rasy a potažmo rasismus. Fanon se domnívá, že je potřeba zkoumat důsledky kolonialismu na rovině sociogeneze, tzn. na rovině sociálních a kulturních vzorců, kde rasistické vzorce jednání vznikají. Východiskem mu ale je kritická studie zkoumající dopady koloniálního uspořádání na psychiku antilských černochů. Tvrdí, že formování subjektivity kolonizovaných - v jeho případě černochů - je ovlivňováno epidermálním a rasovým schématem (Fanon 2011: 111-132); černoch je od počátku své socializace přesvědčován o své méněcennosti a ontologické inferioritě vůči bílému/kolonizátorovi, která se zapisuje do jeho vlastního těla skrze odlišnou barvu kůže. Kolonizace takto formuje taktéž psychiku/subjektivitu 
bílého, jelikož „běloch svět chce; chce ho sám pro sebe. Vidí se jako předurčený pán tohoto světa. Svět si zotročuje. Mezi světem a jím vzniká přivlastňovací vztah" (Fanon 2011: 123). Utlačovatel/kolonizátor je pouze jednou stranou téže mince, tou druhou je utlačovaný/kolonizovaný. Spjatost těchto dvou sociálních pozic se projevuje a realizuje právě skrze sociální jednání, které je vlastní realizující praxí kolonizace.

Politické a sociální uspořádání vrcholí v dělbě práce, kterou nabízí kapitalismus. V ní je černochovi přitknuta role podřízeného pracujícího, který v nejvypjatější podobě - v otroctví - není vůbec pekuniárně odměňován. Takto je dovršena negace černochova těla - sociálně, ekonomicky ani kulturně neexistuje. Aby byla potvrzena tato fatalita koloniální situace, je černoch definitivně zvěcněn tím, že je bělochovým vlastnictvím. Vlastnictví odkazuje k samé hranici fyzického, k linii mezi životem a smrtí, která je věcí bělocha. Fanon proti tomuto uspořádání staví radikální požadavky po zničení takového světa, který je rozdělen ve dví (běloch vs. černoch): Cílem je, ,,[a]by nikdy nástroj neovládal člověka. Aby jednou provždy skončilo zotročování člověka člověkem. Tedy zotročování mě samotného někým jiným“ (Fanon 2011: 190).

Dalším dílem, o kterém bych se zde rád zmínil, je kniha Homiho Bhabhy Místa kultury $(2013)^{14}$. V této publikaci, která je souborem jeho klíčových esejů z roku 1994, hovoří o problémech, jako jsou praktiky vyloučení, pozice druhých/jiných či otázky identity a subjektu. Bhabha se ve svých textech soustředí, ovlivněn Foucaultovou analýzou moci, na koloniální způsoby formováni subjektivity, na možnosti politiky rezistence či na otázku koloniálního jednání. Jeho základní perspektiva je, obdobně jako východisko Frantze Fanona, vztažena $\mathrm{k}$ jedinci, prričemž do určité míry potlačuje hlediska vyšších struktur; jde mu spíše o postižení (inter)subjektivity koloniálního vztahu, který je důležitý pro pochopení koloniální moci a řádu. Zavádí mnoho pojmů, které nejsou vždy zcela precizně vysvětleny (například hybridita, časové zpoždění či jiná sféra), ale zároveň si tím jeho myšlení udržuje vysokou autentičnost a otevřený prostor pro interpretaci. Podstatné je také jeho porozumění stereotypu.

Jako východisko analýz mu slouží každodennost, nebot' právě ona je klíčem k pochopení (nejen) koloniální moci. Mocenské vztahy se rodí v kontaktu mezi subjekty, které jsou samožrejmě determinovány kulturou. Dủležitou rovinou je zde identita, která je formována trrídou, rasou a genderem, ale také tím, co Bhabha označuje jako přesah. Jedná se o osobní rozměr identity, který dovoluje pootevř́t dveře $\mathrm{k}$ jiným sférám, které nejsou lehce detekovatelné skrze zmíněné roviny kultury a společnosti.

Podobně jako jiní postkoloniální autoři a autorky i Bhabha nazírá modernitu ze zkušenosti těch druhých, to jest kolonizovaných, nepreferovaných, utlačovaných. (A to i přesto, že se snaží vyhnout dualitám Západ/Východ, Sever/Jih apod.) Podle Bhabhy modernita nepřišla ke kolonizovaným se zpožděním, ale naopak je od svých počátků př́tomna v jejich každodenních životech. Ono časové zpoždění je imanentním nástrojem modernity k získání nadvlády.

Subjektivní rovina prožívání každodennosti představuje bázi i pro jeho pojem jiné sféry, který připomíná koncept hraničního myšlení Waltera Mignola či myšlení z druhé strany modernity Enriqua Dussela. Jiná sféra se stává místem praktického užití Bhabhovy teorie

14 V poněkud pozměněné podobě vyšla následující pasáž pojednávající o knize Mista kultury v kulturním čtrnáctideníku A2 (Lánský 2013). 
překladu, jelikož ústí v potenciál pro politiku reartikulace. Autor totiž tvrdí, že v překladu (kulturním i jazykovém) je význam vždy vydán napospas působení kontextu, což vytvárí prostor pro tvořivé jednání (Bhabha 2013: 284-311).

V postkoloniální situaci západních měst, kam se během 20. století přistěhovalo velké množství obyvatel z bývalých kolonií, je obtížné formulovat rezistenci proti útlaku tříně. Mnozí autoři hovoří o ztrátě tř́ídního kompasu, jež se dotýká jak majority, tak i sociálně vyloučených či „nepřizpůsobivých“. Politická dezintegrace nižších tříd a jejich neschopnost artikulovat svou pozici je marxisticky založenými autory a autorkami povětšinou vykládána na pomyslné škále směřující od externí manipulace až po nezpůsobilost těchto skupin zorientovat se ve společenském prostoru. Ne že by marxistická analýza nevysvětlovala vznik a působení praktik kapitalistického vykořist'ování; toho jistě schopná je, neumí však své poznatky účinně a srozumitelně formulovat pro ty, jichž se týkají v kontextu koloniálních vztahů. A zde může pomoci bhabhovská či obecněji postkoloniální perspektiva jako jisté doplnění či upřesnění. Zdá se totiž, že omezení ontologického primátu trí́dy v postkoloniálně analyzované modernitě je dáno tím, že tato kategorie nemůže ve změněných, tj. rasializovaných či postkoloniálních podmínkách stačit prostě proto, že odpovídá jinému uspořádání. Koloniální rád a postkoloniální situace vnáší do praktik moci prvek rasy, který oslabuje artikulační sílu třídy.

Výše uvedená tři pojetí vybraných témat (postkolonialismu) u Saida, Fanona a Bhabhy mají sloužit jako ilustrace a př́klad toho, jak postkoloniální kritika postupuje při analýze důležitých fenoménů. Zároveň je př́íznačné, že se $\mathrm{v}$ těchto dílech objevují společné body oscilující kolem pojetí druhého, který je koloniálním řádem považován za méněcennou entitu, kolem praxe rasismu, který vede $\mathrm{k}$ epidermalizované dělbě práce $\mathrm{v}$ globálním kapitalismu, a konečně kolem pojetí identity, která je $\mathrm{v}$ koloniálním řádu formována do značné míry na půdorysu stereotypů. Společným jmenovatelem je potom předpoklad, že dějiny a sociální vztahy fungují $\mathrm{v}$ těsné souvislosti s poznáváním charakteru těchto vztahů. Všechny tři př́klady postkoloniální kritiky mohou dle mého sloužit jako metodologické inspirace pro sociální vědu v České republice.

\section{Dekolonizovaná metodologie}

V této části ve stručnosti představím základní kontury programu dekoloniálního obratu v sociálních vědách a vymezím svou pozici. Dekoloniální obrat si především vynucuje dva důležité kroky. Prvním z nich je radikální odmítnutí (údajně) neutrální pozice myšlení a poznání, a tedy jejich di̊sledná lokalizace. Jeden z nejvýznamnějších současných postkoloniálně orientovaných teoretiků z latinskoamerického prostředí Ramón Grosfoguel (např. Grosfoguel 2002, 2006) tvrdí, že prvním krokem k dekolonizaci myšlení musí být nesmlouvavé připomenutí toho, že myšlení je vždy lokalizované, že je vždy vázané na místo. To znamená, že odmítá výchozí pozitivistickou představu evropského pojetí sociální vědy spočívající v možnosti zaujmout neutrální/objektivní stanovisko vůči zkoumanému předmětu. Zkoumající subjekt je podle Grosfoguela v sociálních vědách naopak vždy zakotven v sociální realitě: ve svém genderu, rase, třídě či etnicitě. Poznávající a poznávané je zároveň ve vztahu, kdy se poznávající i poznávané teprve stává, nebot', jak jsem ukázal výše v souvislosti s prací 
Edwarda W. Saida, je popis světa vždy určitou interpretací a výkladem. V tomto smyslu je postkoloniální odhalení způsobu uchopování druhého vlastně obecným zjištěním, nebot' odhaluje mocenskou či násilnou potenci v poznávání. A to sice v kontextu poznávání, které se rozvinulo v moderní společnosti a které je silně vázáno na modernitu a dějiny. Poznání/ uchopení druhého (a tedy subjektu) je vždy násilné v tom smyslu, že posouvá dosud nevnímaný a nemyšlený objekt do nějakého světla (metodologie), které je vytvořeno předem. Objektivita ve smyslu nad-subjektivní neutrality je z tohoto úhlu pohledu vlastně nedosažitelnou vědeckou hodnotou. Jak je možné být objektivní při popisu např. procesu modernizace, když modernizace jako hluboká historická proměna fungování mnoha společenských mechanismů a institucí (sekularizace, individualizace, industrializace apod.) zasáhla různé aktéry velmi různě? Např. u evropské šlechty či nastupující buržoazie vedly tyto procesy k výrazně jiným změnám sociálního postavení než u peruánských indiánů. Zatímco pro jedny byl proces modernizace a kolonizace otevřením nových možností pro životní strategie, u jiných vedl k permanentní sociální degradaci (sociální smrti) a odsoudil je k epidermalizované pozici v rámci globalizované dělby práce (jak ukazují např̀. výše popsané analýzy Fanona). Neutralita je tedy v kontextu postkoloniálního myšlení pseudoneutralitou, která ve skutečnosti zakrývá pravou povahu jevů.

Dekoloniální obrat vyžaduje proměnu epistemologických východisek při zkoumání společnosti a člověka. Za prvé jde o to, pokusit se odhalit zvnitřnělé rétorické a sémiotické formule, které udržují koloniální řád či postkoloniální situaci. V tomto kontextu je potřeba nalézt problematické momenty ve výrocích a pojmových kategoriích, které uchopují (koloniálního) druhého v poznání a připravují tak půdu pro uchopení ve skutečnosti. Je třeba analyzovat nejen povrchní projevy koloniálního diskursu, ale také filosofické základy těchto projevů (viz výše u zkoumání epistemologie). Proti tomuto koloniálnímu způsobu myšlení, který vychází z epistemologie a ontologie evropské filosofie, vytváŕí např. americko-mexická sociální teoretička Chela Sandoval nikoliv nějaké postmoderní vymezení metodologie vědy, ale naopak vymezení dekoloniální, které je založené na lásce, jež odpovídá radikální a naprosté otevřenosti vlastního já vůči druhému (Sandoval 2000). Požaduje v epistemologickém smyslu potlačení vlastních východisek a kulturních předpokladů (jako základ pro dialog) a v ontologickém smyslu svou substituci (nahrazení sebe sama) - tedy vlastně ochotu zemřít - ve jménu transontologického, tj. ve jménu toho, co překračuje rozdílné kulturní okruhy a kontexty. V tomto smyslu je základem pro hledání nějakých společných všelidských východisek - zkrátka pro to, čemu Dussel říká transmoderní pluralismus ${ }^{15}$ - vlastně potlačení sebe sama.

Ve své vlastní vědecké práci uplatňuji kriticko-teoretickou perspektivu obohacenou o postkoloniální perspektivu. Teoretická práce stejně jako empirický výzkum vycházející z metodologie Frankfurtské školy jsou postaveny především na odmítání pozitivistického přístupu k sociologickému výzkumu, který je klasicky založen mj. na mocensky působící iluzi možného nestranného poznání. Poznání je vždy vytvářeno v souvislosti s určitými zájmy (Habermas 1967) a z metodologického hlediska je tedy upř́ímnější se k vlastní zakotvenosti

15 Více viz např. Dussel (2012: 551-553). 
reflexivně vztáhnout. Moje práce je v kontextu tématu tohoto článku ovlivněna minimálně tím, že se považuji za kritického teoretika a antirasistu.

\section{Inspirace postkolonialismu pro sociální vědy v českém kontextu}

Hlavní motiv, který je možné z postkolonialismu čerpat, spatřuji ve výše popsaném pojmu druhého a v kritice klasických evropských vědeckých východisek a postupo̊, která pramení z postkoloniálního pojetí druhého. Česká společnost ${ }^{16}$, byt' zcela prokazatelně neměla kolonie, je společností, která v současném globalizovaném světě patří spíše mezi společnosti centra či jádra a jako taková využívá výhod, které jí toto strukturální postavení přináší. Zároveň má i své druhé: minority, které jsou také arbitrárně kódovány jako inferiorní. Popis/analýza/ /kritika postkoloniální situace tak mnohé napovídá, anebo může minimálně skrze metodologické a tematické inspirace napovídat také o stavu české společnosti. Z těchto důvodů se zde zaměřím na několik tematických inspirací postkolonialismu pro český kontext sociální vědy. Popíši dva příklady využití postkoloniálních východisek a metodologie při formulování výzkumného záměru, a to na příkladu studia proměny práce v širším kontextu a na př́ikladu analýz soužití mezi majoritou a minoritou Romů v České republice.

Mezi klíčová témata současné doby v České republice je možné řadit analýzy příčin chudoby či obecněji proměny práce a otázku soužití majority a romské minority. V první zmíněné oblasti témat se jako klíčové zdá vyřešit otázku proměňující se podoby práce v pozdním či současném kapitalismu. Práce je ,[...] vnímána jako zdroj bohatství a eliminace bídy, jako základ veškerého tvoření, budoucnosti a pokroku i společenského řádu. Je považována za integrující prvek společnosti, jejíž občané byli a jsou chápáni především jako občané pracujícíi“ (Mareš 2004: 37). Avšak právě v současné době se dostává pod výrazný tlak procesů globalizace a neoliberálního kapitalismu a dochází k proměně jejích základních atributů, které práci zajišt’ovaly popsanou určující roli v moderní společnosti (srov. Munck 2002; Standing 2009). Každopádně je možné říci, že práce (jako činnost přetvářející př́írodu) je vázána nejen na klíčovou funkci téměř všech sociálních institucí (kdy touto funkcí rozumím cíl společnosti spočívající v pokračování daného systému, tj. společnosti), ale také na mocenské mechanismy, které se v dané společenské formaci rozvinuly. A právě zde je možné vidět základní linku spojující otázku práce s postkolonialismem.

V projektu určité genealogie práce by bylo cílem zkoumat různé aspekty sociálních interakcí, které jsou zprostředkovány prací, a to v širším procesu modernizace (s tím, že je samozřejmě možné výzkum zúžit časově či geograficky). Práci ve smyslu sociálního vztahu (člověk-příroda-člověk) by zde bylo možné analyzovat jako projev sociálních praktik, které konstituují lidskou subjektivitu a zároveň vytvářejí základní pojivo společnosti jako takové,

16 Zcela záměrně se vyhýbám popisu možností, které poskytuje postkolonialismus pro zkoumání $\mathrm{v}$ českém kontextu takříkajíc z druhé strany, tzn. z hlediska zkoumání české společnosti jako v minulosti různými způsoby a do jisté míry kolonizované (např. německým/rakouským vlivem) či kolonizující (Slovensko či Zakarpatská Ukrajina) společnosti. Takové uchopení problematiky vývoje české společnosti je jistě důležité, avšak považuji jej za spiše historické téma. V tomto textu jsem se pokusil vypointovat jinou linii postkoloniálního odkazu pro českou sociální vědu. 
nebot' ohraničují klíčovou sociální činnost člověka vůbec, a to jeho primární vazbu na př́rodní okolí. Práce je zde projevem i zdrojem sociability člověka vůbec a zároveň prostorem, kde se realizuje moc. V tomto kontextu navrhuji použít $\mathrm{k}$ analýze tři modely (ideální typy), o nichž se domnívám, že určitým způsobem organizují práci: otroctví, placenou práci a prekarizovanou práci. Tyto tři modely by bylo potom možné vztáhnout ke třem typům moderních aktérů: otrokům, proletariátu a prekariátu. Tyto dvě typologie vymezují prostor pro vlastní analýzy: je možné se například zaměřit na roli otroctví při formování kapitalismu (Williams 1944) anebo na analýzy současného procesu prekarizace práce na Západě (Standing 2009), jehož důsledky v mnohém připomínají spíše podmínky raně průmyslové modernity 19. století.

Vytvořený základní rámec analýzy práce potom vymezuje prostor pro aplikaci postkoloniálního myšlení: jako ústřední otázka takového výzkumu práce se již nyní - při pouhém naznačení základních kontur - ukazuje proměnlivost diskursivních praktik moci, které realizují v dané době „normální“ podoby práce, a to skrze panující sociální vzorce (a tedy jednání aktérů). Nejsme ve skutečnosti schopni nalézt až znepokojivě podobný prvek v otroctví či v placené práci, který nabývá podoby diskursivnich praktik, které formují subjekty tak, jak daný ekonomický režim (podle fáze, ve které se nachází) právě vyžaduje? Není možné tyto diskursivní praktiky spatřovat $\mathrm{v}$ různých formách uchopení druhého vedoucího $\mathrm{k}$ jeho disciplinaci $\mathrm{v}$ pracovním procesu podle potřeb ekonomického řádu? Není trvalým, byt' možná dočasně $\mathrm{v}$ určitých historických a sociálních kontextech vlastně menšinovým, rysem modernity právě to, co se s odzbrojující silou odhalilo v kolonizaci: a to naprosté zvěcnění druhého? A neděje se tak právě skrze práci pojímanou jako základní intersubjektivní vztah? Neodhaluje tak kolonialita něco určujícího pro modernitu? A není potom postkoloniální myšlení jedním z nejdůležitějších kritických diskursů sociální vědy vůbec? To jsou otázky, na které není možné na tomto místě odpovědět.

Zároveň je $\mathrm{v}$ této souvislosti vhodné připomenout, že proměny organizace a charakteru práce $\mathrm{v}$ postkolonialitě/modernitě vedly $\mathrm{k}$ tomu, že při analýze dělby a organizace práce ztratila kategorie třídy svůj ontologický primát. V České republice se tento moment projevuje tím, že problém anticigánských nálad obtížně překládáme do jazyka analýz vykořistování či neoliberalismu. Připustit, že tento problém může pomoci vyřešit bhabhovské porozumění naší situaci, by znamenalo otevř́i artikulaci jiným sférám, které Bhabha dává do souvislosti s nahrazením třídy konceptem společenství. Výrazem boje proti stereotypu, který byl identifikován jako páteř moci subjektivizace, je potom snaha o jeho překroucení či lépe řečeno reartikulaci. Jak jinak chápat akce iniciativy „Čechy v ČR nechceme“ než právě jako projevy praktické politiky reartikulace? Nástrojem společenství je podle Bhabhy umělecká aktivita, která vytvář́ nový prostor $\mathrm{v}$ občanské společnosti, respektive i mimo ni. Role umění při artikulaci postkoloniálních dějin byla skutečnou praxí odporu proti koloniální moci. Rozumění jak jazyku společenské kritiky, tak i subverzivní umělecké řeči a schopnost oba tyto kódy používat - to jsou základní předpoklady k propojení politiky odmítající sociálně-ekonomické důsledky neoliberálního vládnutí (jakési kolonizace veřejného prostoru kapitálem) a politiky reartikulace stereotypů a řečových projevů moci. Nejde tedy o to, řešit rozpor mezi marxisticky orientovanou kritikou neoliberalismu a postkoloniálně orientovanou kritikou kultury, ale spíše o jejich praktické spojení. 
Dalším významným problémem, u kterého je, jak se zdá, na místě použít postkoloniální myšlení k inspiraci sociálních věd, je problém soužití majoritní společnosti a menšin; konkrétně potom Romů. Zároveň je toto téma velmi silně spojeno s tématem předešlým. Romové jsou často vnímáni na různých rovinách abstrakce - od novinářského žargonu přes vyjádření politiků až po kvazi-seriózní výzkumy - na základě mnohých stereotypizovaných tvrzení či přesvědčení (nejviditelnější z nich je používání kryptorasistického označení nepřizpůsobiví). V otázce situace Romů a v otázce postupné pauperizace obyvatelstva (např. Holý 2013) je možné spatřovat potenciál pro použití postkoloniálně orientované (či alespoň informované) metodologie založené na výše popsané sociální teorii práce a vlastně také teorii společnosti.

Romové představují skupinu, na kterou patrně do značné míry doléhají důsledky finanční a ekonomické krize nejvíce, anebo pravděpodobně nejdříve ${ }^{17}$. Zcela klíčová je zde rovina analýzy chudoby v tzv. vyloučených lokalitách, kde životní podmínky mnohdy připomínají situaci v zemích třetího světa. Tato situace je v mnoha bodech podobná situaci druhých v koloniálně či postkoloniálně uspořádaném světě: Romové jsou vnímáni jako Jiní, jejichž životní styl, identita a barva kůže neodpovídá ,normálu“. Jejich zhoršující se sociální situace a postavení ve společnosti je aparátem sociálních a kulturních institucí a vzorců interpretováno jako důsledek jejich jinakosti. Bludný kruh rasistického uchopení jejich situace může protnout právě postkoloniálně orientovaná kritika mediálního (a částečně také odborného) diskursu, která by nabídla reflexi stereotypizovaného vztahování se k těmto druhým. Byla by to kritika bolestná, nebot' by musela kriticky zasáhnout jádro vztahování se Čechů, resp. rozhodující části majority, k jinakosti/odlišnosti.

V tomto kontextu lze využít například Bhabhovu postkoloniální kritiku mocenských mechanismů a praktik jako metodologickou inspiraci při analýze anticiganistického jednání i promluv. Stanoviska typu „cikáni jsou vyžírkové“, ,„at’ táhnou do práce“, „my je živíme“

17 Jedním ze způsobů, jak je možné operacionalizovat dopad ekonomické krize, byt' velmi hrubě, je prozkoumat otázku zaměstnanosti a porovnat ji u Romů a majority, a to konkrétně v souvislosti s ekonomickou krizí z roku 2008. Nezaměstnanost, resp. postavení na trhu práce, zde potom hraje roli základního třídicího ukazatele sociálně-ekonomické struktury společnosti, nebot' ve společnosti práce je zaměstnání klíčovou strategií zajištění podmínek pro život populace. „Právě marginální pozice Romů na trhu práce se po roce 1990 stala hlavní charakteristikou jejich sociálního postavení a zdrojem jejich sociálního vyloučení“ (Sirovátka 2003: 12). V mezinárodní zprávě srovnávající sociální situaci Romů ve vybraných státech EU se doslova uvádí: „V kontextu ekonomické krize je nicméně smysluplné předpokládat, že speciálně u nekvalifikovaných prací platí, že intenzivnější boj o práci bude více Romů častěji stavět do znevýhodněné pozice při usilování o zaměstnání“ (European Union Agency for Fundamental Rights /FRA/ 2012: 16). Navíc na vyšší míru nezaměstnanosti u Romů než u majority opakovaně poukazují i Zprávy o stavu romských komunit vydávané jedním z přidružených orgánů Úřadu vlády České republiky. Již v roce 2008 tato zpráva konstatuje souvislost mezi ekonomickou krizí a ne/zaměstnaností Romů v negativním ohledu (Rada vlády pro záležitosti romské menšiny 2009: 36) a obdobně je ekonomická krize zmíněna jako jeden z faktorů špatné sociální situace Romů také ve zprávě za rok 2012 (Rada vlády pro záležitosti romské menšiny 2013: 10). Vzhledem k nerovnému př́stupu Romů k pracovnímu trhu i za nekrizového stavu ekonomiky je zřejmé, že v situaci ekonomické krize působí určitý synergický efekt: zjednodušeně řečeno méně práce pro všechny znamená ještě méně práce pro Romy než za nekrizového stavu (srov. s Rada vlády pro záležitosti romské menšiny 2008: 36). 
jsou projevem řečových aktů, které odhalují podstatu neoliberálního diskursu, v němž se subjektivita formuje na základě opozice slušný / sociálně vyloučený, přičemž nástrojem tohoto procesu je stereotyp. Ten je $\mathrm{v}$ Bhabhově pojetí klíčovým piliŕrem koloniálního vládnutí. Percepce každodennosti majority doléhající $\mathrm{k}$ uším jejich druhých např. přes rasistické pokřiky či prostřednictvím apartheidem zavánějících institucionálních aktů zvolených autorit (např. vyhlášky kategorizující občany či zakazující určité projevy životního stylu) se nápadně podobá násilí kolonizátorů, jež spočívalo na podobných oporách subjektivizační praxe: na institucích a na řeči. Stereotyp je podle Bhabhy na jedné straně zdrojem moci a na straně druhé také projevem znepokojení a slabosti.

Jakým způsobem by musela $\mathrm{v}$ tomto kontextu probíhat lokalizace myšlení/vědění $\mathrm{v}$ souvislosti s vymezenými okruhy témat, $\mathrm{v}$ jejichž rámci je využitelný koncept postkolonialismu? Především by si patrně musel český vědecký diskurs přiznat, že se jedná o diskurs formulovaný z pozice majority. Musel by tematizovat otázku této své fundamentální zakotvenosti a např. by musel otevř́t možnost i pro formulaci/tematizaci klíčových otázek analýzy chudoby (sociálního vyloučení) z pozice vyloučených. To znamená, že by musel nějakým způsobem tematizovat otázku reprezentace nejvíce dotčených aktérů prímo $\mathrm{v}$ rámci analytické práce a také otázky spojené s diskursivní praxí udržující stávající sociální rád. V této souvislosti je např́klad možné provádět diskursivní a obsahové analýzy oficiálních materiálů (na jejichž vzniku se mnohdy spolupodílí vědecká komunita) zaměřených na problematiku chudoby, sociálního vyloučení a interetnického soužití. Je možné analyzovat způsob vzniku a obsah těchto materiálů a na ně navazujících politik. V obou př́padech se totiž jedná o jistá vyjádření společenského étosu či nějaké jeho části, která legitimizuje a zároveň zobrazuje společensky (majoritně) akceptovatelné formy jednání v těchto souvislostech. Lze sledovat, do jaké míry se „vyloučeni““ na jejich tvorbě (ne)podílejí, prípadně kdo za ně mluví či je reprezentuje.

Český vědecký diskurs by dále mohl seriózně prozkoumat otázku, zda režimy práce, které se prosazují v současném pracovně úsporném řádu kapitálu, nejsou založeny na rasistických diskursivních a sémiotických formacích. Do jaké míry se kategorie „nepřizpůsobivý““ překrývá s kategoriemi jako „vyloučený“, „chudý“, „Rom“, „Ukrajinec“, „,bezdomovec“ apod. Toto překrývání lze zkoumat jak na rovině oficiálního diskursu (obdobně Hejnal 2012), tak na rovině parciálního diskursu některých sociálních aktérů (obdobně Šimíková a Vyhlídal 2010; Císař a Walach 2013), přičemž inspiraci postkoloniálními studii lze využít př̌i ověřování toho, do jaké míry je oporou pro rasistický diskurs i euroatlantická filosofie a sociální věda. Stejně tak se lze věnovat otázce, proč a v jakých situacích někteří Romové přijímají diskurs společensky dominantní skupiny a uvádějí, že „,,většina Romů je nepřizpůsobivých“, a proto jejich větší počet na jednom místě vždy znamená problémy v interetnickém soužiti““ (Walach 2013). Při této analýze by bylo možno vycházet např. z Fanonových postřehů ohledně zvnitřnění koloniálního uspořádání samotnými subjekty kolonizace (tedy těmi, kteří jsou subjektivizováni jako kolonizovaní).

Dále by český vědecký diskurs mohl problematizovat otázku, zda v současné době nedochází v rámci globalizace $\mathrm{k}$ reverznímu pohybu institucionálních vzorců: $\mathrm{k}$ přenosu diskursivních praktik moci v oblasti práce (které jsou - jak jsem ukázal výše - výrazně rasializované či epidermalizované) z kolonizovaných zemí do zemí centra či semiperiferie (kam je možné zařadit i Českou republiku). Není vlastně zmíněná prekarizace práce projevem 
určitého reverzního působení koloniálních dispozitivů moci $\mathrm{v}$ oblasti práce zpět $\mathrm{v}$ jádrových či semiperiferních zemích, a to v pomalu se šiřící podobě? Nezobrazuje proces postupné pauperizace obyvatelstva, která se nejčastěji projevuje jako ztráta klíčových jistot modernity (např. Keller 2011), to, že současný neoliberální kapitalismus již opouští praxi epidermalizace sociálního vyloučení a jako novou praxi zapojuje právě pauperizaci sociálního vyloučení? Nejvhodnější metodou pro otestování těchto hypotéz by byly nejrůznějšś komparace koloniálních režimů a soudobého fungování režimů práce a moci v jádrových státech světového uspořádání. Stručně řečeno jedna z otázek, které před nás postkoloniální studia kladou, zní, zda nebudou příšími černými - tedy těmi, kteří pracují v různých režimech (polo) nucených prací - prostě ti, kteří jsou chudí? Nebude společnost hyperbolizovaného neoliberálního kapitalismu vlastně společností celoplanetárně uskutečněných praktik koloniální moci v poněkud pozměněných podmínkách - jako derasializovaný rasismus? Toto jsou jen některé z otázek, které by postkoloniálně informovaná sociální věda a postkolonialismus obecně mohly pomoci vyřešit.

Takto do určité míry provizorně a předběžně popsané základní kontury postkoloniálně orientovaného projektu analýz genealogie práce a sociálního vyloučení, který může napomoci porozumění současné společnosti, je samozřejmě především výzvou k dalšímu rozpracování. Toto rozpracování má před sebou značné množství překážek. Některé jsou teoretické či obecně vědecké. Jiné jsou politické. Právě ty zároveň mohou být snadněji překonány pomocí postkoloniálního myšlení, a to pomocí, přičemž zde si vypůjčím a parafrázuji obrat Pavla Barši (2011), vzpoury proti řádu poznání/moci a sociální praxe. Nutnou podmínkou této vědecké aktivity je tak přesah $\mathrm{k}$ politickému rozměru vědecké činnosti, nebot' samotný cíl analýz zasahuje jádro politické moci. Pro postkoloniálně informovanou sociální vědu, která usiluje nejen o svou vlastní dekolonizaci, ale také především o vyznačení bolestných hranic a způsobů fungování globální moci, platí tedy původně feministické heslo - osobní je politické - $\mathrm{v}$ radikálně rozšîřené a prohloubené podobě: sociální je politické.

\section{Literatura}

BARŠA, Pavel. Orientálcova vzpoura (a dalši texty z let 2003-2011). Praha: Dokořán, 2011. ISBN 978-80-7363-374-5.

BHABHA, Homi. Mista kultury. Praha: Tranzit, 2013. ISBN 978-80-87259-16-0.

CÉSAIRE, Aimé. Rozprava o kolonialismu. In HAVRÁNEK, Vít (ed.). Postkoloniální myšlení II. Praha: Tranzit, 2011, s. 86-115. ISBN 978-80-87259-14-6.

CÍSA ̌̌, Ondřej a Václav WALACH. „Jako ghetto - ty ublížíš mně, já ublížím tobě.“ Bezpečnost a pouliční násilí v sociálně vyloučené lokalitě. Lidé města, 2013, roč. 15, č. 3, s. 391-417. ISSN 1212-8112.

DUSSEL, Enrique. Filosofía de la Liberación. Mexico City: Editorial Edicol, 1977.

DUSSEL, Enrique. The Invention of the Americas. Eclipse of "the Other" and the Myth of Modernity. New York: Continuum, 1995. ISBN 0-8264-0796-X.

DUSSEL, Enrique. Politica de la liberación. Historia mundial y crítica. Madrid: Editorial Trotta, 2007. ISBN 978-84-8164-924-6.

DUSSEL, Enrique. Ética de la liberación en la edad de la globalización y de la exclusión. Madrid: Editorial Trotta, 2009a. ISBN 978-84-9879-090-0. 
DUSSEL, Enrique. Política de la liberación II. Arquitectónica. Madrid: Editorial Trotta, 2009b. ISBN 978-84-9879-034-4.

DUSSEL, Enrique. Nový věk v dějinách filosofie: světový dialog mezi filosofickými tradicemi. Filosofický časopis, 2012, roč. 60, č. 4, s. 537-554. ISSN 0015-1831.

EUROPEAN UNION AGENCY FOR FUNDAMENTAL RIGHTS (FRA). The situation of Roma in 11 EU Member States. Survey results at a glance. Luxembourg: Publications Office of the European Union, 2012. ISBN 978-92-9192-932-0.

FANON, Frantz. Černá kůže, bílé masky. Praha: Tranzit, 2011. ISBN 978-80-87259-12-2.

FOUCAULT, Michel. Subjekt a moc. In FOUCAULT, Michel. Myšleni vnějšku. Praha: Herrmann \& synové, 2003, s. 195-226. ISBN 80-239-2454-0.

FOUCAULT, Michel. Slova a věci. Brno: Computer Press, 2007. ISBN 978-80-251-1713-2.

GANDHI, Leela. Postcolonial Theory. A Critical Introduction. Sydney: Allen \& Unwin, 1998. ISBN 1-86448-431-4.

GIDDENS, Anthony. Sociologie. Praha: Argo, 1999. ISBN 80-7203-124-4.

GROSFOGUEL, Ramón. La descolonización de la economía política y los estudios postcoloniales: Transmodernidad, pensamiento fronterizo y colonidad global. Tabula Rasa, 2006, č. 4, s. 17-48. ISSN 0724-4002.

GROSFOGUEL, Ramón. Dekolonizace západních uni-verzalismů. Dekoloniální pluri-verzalismus od Aimé Césaireho k zapatistům. In HAVRÁNEK, Vít a Ondřej LÁNSKÝ (eds.). Postkoloniální myšleni IV. Praha: Tranzit, 2013, s. 184-205. ISBN 9788087259245.

GROSFOGUEL, Ramón a Ana M. CERVANTES-RODRÍGUEZ (eds.). The Modern/Colonial/ /Capitalist World-System in the Twentieth Century. Global Processes, Antisystemic Movements, and the Geopolitics of Knowledge. Westport: Greenwood Press, 2002. ISBN 0-275-97197-X.

HABERMAS, Jürgen. Poznání a zájmy. Filosofický časopis, 1967, roč. 15, č. 2, s. 189-198. ISSN 0015-1831.

HEJNAL, Ondřej. Nacionalismus, multikulturalismus, sociální vyloučení a „sociálně nepřizpůsobivi““: Analýza dominantního politického diskursu v České republice (2006-2011). AntropoWebzin, 2012, č. 2, s. 47-66. ISSN: 1801-8807.

HOLÝ, Dalibor. Problém pracující chudoby se v Česku zhoršuje [online]. Praha: Český statistický úřad, 2013. [cit. 9. 9. 2013]. Dostupné z: http://www.czso.cz/csu/2013edicniplan.nsf/c/2D004943CA.

KELLER, Jan. Nová sociální rizika a proč se jim nevyhneme. Praha: Sociologické nakladatelství, 2011. ISBN 978-80-7419-059-9.

LÁNSKÝ, Ondřej. Genealogie koloniálního strádání: inspirace a konstelace Dusselovy filosofie osvobození. Filosofický časopis, 2012, roč. 60, č. 4, s. 555-574. ISSN 0015-1831.

LÁNSKÝ, Ondřej. Síla překrucování stereotypů. Postkoloniální bhabhovské inspirace pro naši dobu. $A 2$, 2013, roč. 9, č. 19, s. 3. ISSN 1803-6635.

MALDONADO-TORRES, Nelson. Against War. Views from the Underside of Modernity. Durham: Duke University Press, 2008. ISBN 978-0-8223-4170-3.

MALDONADO-TORRES, Nelson. Thinking through the Decolonial Turn: Post-continental Interventions in Theory, Philosophy, and Critique. Transmodernity, 2011, roč. 1, č. 2, s. 1-15, ISSN 2154-1316.

MALDONADO-TORRES, Nelson. O kolonialitě a bytí. Poznámky o zrodu jedné koncepce. In HAVRÁNEK, Vít a Ondřej LÁNSKÝ (eds.). Postkoloniální myšlení IV. Praha: Tranzit, 2013, s. 206-237. ISBN 9788087259245.

MAREŠ, Petr. Od práce emancipující k práci mizející. Sociologický časopis, 2004, roč. 40, č. 1-2, s. 37-48. ISSN 0038-0288.

MEMMI, Albert. The Colonizer and the Colonized. Boston: Beacon Press, 1991. ISBN 978-0-8070-0301-5. 
MEMMI, Albert. Dvě odpovědi člověka žijícího v koloniálním područí. In DUBOVICKÝ, Ivan (ed.). Zprostředkování a prostředníci v kultuře: antologie francouzských společenských věd. Praha: Francouzský ústav pro výzkum ve společenských vědách, 1997, s. 125-138. ISBN 80-901759-9-6.

MIGNOLO, Walter D. Local Histories/Global Designs. Coloniality, Subaltern Knowledges, and Border Thinking. New Jersey: Princeton University Press, 2000. ISBN 978-0-691-00140-1.

MUNCK, Ronaldo. Globalisation and Labour. The New 'Great Transformation'. London: Zed Books, 2002. ISBN 1-84277-071-3.

QUIJANO, Aníbal. Coloniality and Modernity/Rationality. Cultural Studies, 2007, roč. 21, č. 2, s. 168-178. ISSN 0950-2386.

RADA VLÁDY PRO ZÁLEŽITOSTI ROMSKÉ MENŠINY. Zpráva o stavu romských komunit v České republice za rok 2008 [online]. Praha: Rada vlády pro záležitosti romské menšiny, 2009. [cit. 14. 3. 2014]. Dostupné z: http://www.vlada.cz/cz/ppov/zalezitosti-romske-komunity/dokumenty/ zprava-o-stavu-romskych-komunit-v-ceske-republice-za-rok-2008-60515/.

RADA VLÁDY PRO ZÁLEŽITOSTI ROMSKÉ MENŠINY. Zpráva o stavu romské menšiny v České republice za rok 2012 [online]. Praha: Rada vlády pro záležitosti romské menšiny, 2013. [cit. 14.3.2014]. Dostupnéz: http://www.vlada.cz/assets/ppov/zalezitosti-romske-komunity/dokumenty/ III_Zprava_pripominky_1_11_2013.pdf.

SAID, Edward W. Orientalismus. Západni koncepce Orientu. Praha: Paseka, 2008. ISBN 978-80-7185921-5.

SANDOVAL, Chela. Methodology of the Oppressed. Minneapolis: University of Minnesota Press, 2000. ISBN 0-8166-2736-3.

SIROVÁTKA, Tomáš. Exkluze Romů na trhu práce a šance na jejich inkluzi. Sborník prací Fakulty sociálních studií MU. Sociální studia, 2003, č. 10, s. 11-34. ISSN 1803-6104.

STANDING, Guy. Work after Globalization. Building Occupational Citizenship. Cheltenham: Edward Elgar, 2009. ISBN 978-1-84844-164-4.

SUŠOVÁ-SALMINEN, Veronika. Kolonialita jako druhá tvář modernity. K současné latinskoamerické postkoloniální kritice modernity. Historická sociologie, 2012, č. 1-2, s. 75-94. ISSN 1804-0616.

ŠIMÍKOVÁ Ivana a Jiří VYHLÍDAL. Sociální konstrukce systému sociální ochrany: Administrace klientů jako prostor interpretace. Sociální studia, 2010, roč. 7, č. 2, s. 135-156. ISSN 1803-6104.

TAYLOR. Charles. Sekulární věk. Dilemata moderni společnosti. Praha: Filosofia, 2013. ISBN 978-80-7007-393-3.

THIONG'O, Ngũgĩ Wa. Jazyk africké literatury. In HAVRÁNEK, Vít (ed.). Postkoloniální myšleni II. Praha: Tranzit, 2011, s. 226-255. ISBN 978-80-87259-14-6.

TODOROV, Tzvetan. Dobyti Ameriky. Problém druhého. Praha: Mladá fronta, 1996. ISBN 80-204-0582-8.

WALACH, Václav. Dialektika cigánské férovky. Př́íspěvek ke kritické antropologii bezpečnosti. AntropoWebzin, 2013, č. 4, s. 165-174. ISSN: 1801-8807.

WALLERSTEIN, Immanuel. The Modern World-System I. Capitalist Agriculture and the Origins of the European World-Economy in the Sixteenth Century. New York: Academic Press, 1974. ISBN 0-12-785920-9.

WALLERSTEIN, Immanuel. The Modern World-System II. Mercantilism and the Consolidation of European World Economy, 1600-1750. New York: Academic Press, 1980. ISBN 0-12-785924-1.

WALLERSTEIN, Immanuel. The Modern World-System III. The Second Era of Great Expansion of the Capitalist World-Economy, 1730-1840s. San Diego: Academic Press, 1989. ISBN 0-12-785926-8.

WALLERSTEIN, Immanuel. The Modern World-System IV. Centrist Liberalism Triumphant, 1789-1914. Berkeley: University of California Press, 2011. ISBN 978-0-520-26761-9.

WILLIAMS, Eric. Capitalism and Slavery. Richmond: The University of North Carolina Press, 1944. 


\section{Autor}

Ondřej Lánský se ve své práci soustředí na kritickou teorii soudobé společnosti a postkoloniální myšlení. Ve svých analýzách se zaměřuje jednak na civilizační analýzy sdílených morálních systémů (např. spravedlnosti) a dále na postkoloniální zkoumání role otroctví při formování kapitalismu a proměn práce $\mathrm{v}$ pozdním/současném kapitalismu. Působí ve Filosofickém ústavu AV ČR a vede Katedru filosofie na Technické univerzitě v Liberci. Kontakt: ondrejlansky@gmail.com 